\title{
Glasnost lost in French government's science policy
}

Paris

THE Conseil Superieur de la Recherche et de la Technologie (CSRT), established by the previous French socialist government with a legal right to be consulted on civil science and technology budget proposals, is being bypassed by the present Conservative government. For the second year in succession, the CSRT will not be shown the budget until after the proposals have been put to parliament next month, defeating the purpose of consultation, emasculating the committee and possibly infringing a 1982 decree.
The CSRT was set up in 1983 under the chairmanship of the then research and industry minister, Jean-Pierre Chevènement, ostensibly to enable his ministry to shape its policy to suit the longterm needs of science and industry. A practice of open debate was inscribed in the CSRT's legal constitution, with the 40strong membership of academics and industrialists encouraged to play a major and public role in the summer run-up to the annual budget debate. Although it endorsed plans for radical reform in French science and technology, the CSRT

\section{New York launches test}

\section{programme for AIDS virus}

\section{Washington}

NEw York, the US state with the second highest incidence of acquired immune deficiency syndrome (AIDS), will be the first to take steps on its own to assess the spread of the AIDS virus within its borders. Last week, Governor Mario M. Cuomo announced that the New York state health department will screen 100,000 blood samples selected randomly from routine specimens taken at state hospitals for antibodies to human immunodeficiency virus (HIV), the virus causing AIDS.

The $\$ 3.4$ million study will give public health officials an indication of how far the virus has spread through different subpopulations and regions of the state. This will allow them to assess the burden the disease will place upon health care and insurance systems, and help to target preventive educational campaigns. Cuomo cautioned against "grasping for simplistic answers to complex questions" or "believing ... that if everyone were simply tested for the virus, that that in itself would stop it", and stressed the importance of a scientific approach to studying the spread of the disease.

The tests will be anonymous, and patients will not be notified of the results. The samples used in the study will be accompanied only by clinical information that will enable researchers to determine if the donor fell into a high-risk group, such as homosexuals or intravenous drug abusers. Testing will begin in October, and is expected to take six months to a year to complete.

The New York study will be one of the first nonmilitary sampling programmes in the US. The Department of Defense has been screening its personnel since 1986 . But HIV frequency in the military is unlikely to be representative of the population at large.

The Centers for Disease Control (CDC) set up a regional programme very similar to the New York study in late 1986. Since then, four "sentinel hospitals" have been monitoring 300 anonymous specimens a month for antibodies to HIV.

According to Timothy Dondero, the director of the study, testing anonymous samples to construct trends and levels of HIV prevalence is the "only ethical way". First announcement of results will come after Dondero has six months of data.

The protocol for the nationwide random survey for HIV, announced by Secretary of Health and Human Services Otis Bowen at the Third International Conference on AIDS in June, is still being developed. The national survey is intended to test the blood of 45,000 people in order to estimate the number who are infected with the virus in the United States.

Carol Ezzell

\section{AIDS does not discriminate.}

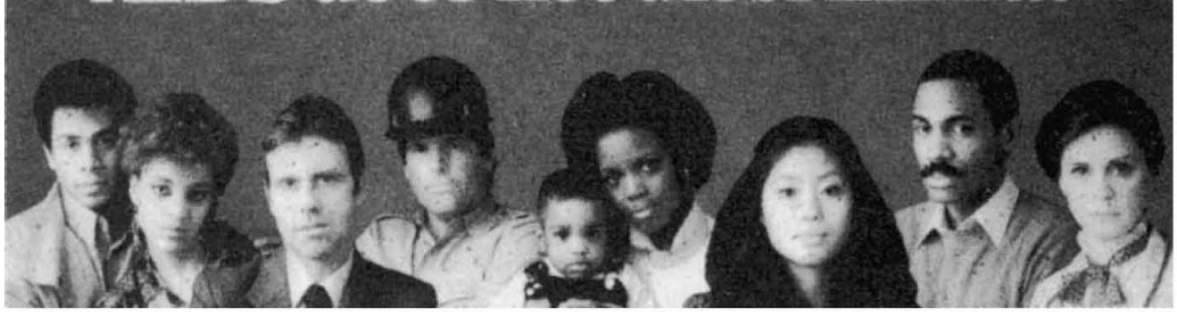

held the view that fundamental research would need to grow steadily to meet future unpredictable technology needs.

With the change in government in March 1986, and a shift in emphasis from public sector to industrial research, the CSRT found itself increasingly excluded from the corridors of power. Neither the 1987 science budget nor the controversial university reforms, which ended in the resignation of their initiator, education and research minister Alain Devaquet, were discussed with the CSRT. Touchstones of the previous relationship between government and CSRT, such as the legal commitment to see recruitment of young scientists to the state research centres grow by 1,400 per year, have also been abandoned. Some forecasts predict that no new research posts will be created this year in the principal research centres of the Centre National de la Recherche Scientifique (CNRS).

The diminishing voice of fundamental research is also reflected in the composition of the new CSRT committee, with a two-year term of office, named last month by Minister for research and higher education, Jacques Valade. Jean-Pierre Causse, who comes from industry, replaces Françoise Kourilsky as executive vicechairman of the committee. Valade's influence on the research budget has also been dramatically reduced. Last year, 75 per cent of the research budget was transferred to the industry ministry. As the CSRT was set up to advise the research minister, its power has effectively been reduced in direct proportion.

According to a CSRT report*, which has not been endorsed for publication by the government, a change in the way the research budget is calculated has enabled the government to sidestep its legal obligation to involve the CSRT in the impending budget debate. The 1982 decree requires consultation on the budget for civil research and technological development (BCRD), which was calculated by pooling research expenditure forecasts from different ministries, but excluded defence and salaries for university dons. In 1986, the incoming government created a new budget reference, the 'budgetary effort for research and development' (EBRD), which includes spending on defence and post and telecommunications. Because the BCRD is now an a posteriori abstraction, worked out from the EBRD, the legal obligation to consult the CSRT has become meaningless.

In the past, 'indiscretions' on the part of the CSRT gave the press a foretaste of the autumn science budget as early as July. This year it seems that the CSRT, as well as the public, will have to wait until September.

Peter Coles

4 Années de Conseils. Conseil supérieur de la recherche et de la technologie. March 1987 